\title{
Community Participation in Decision Making Processes in Urban Planning: The Case of Kaunas
}

\author{
M.A. Laura Jankauskaitè-Jurevičienè (D), Dr. Aušra Mlinkauskienė
}

a and b Kaunas University of Technology, Civil engineering and architecture faculty, Kaunas, Lithuania

Email 1: laura.jankauskaite-jureviciene@ktu.It,Email 2: ausra.mlinkauskiene@ktu.It

\section{ARTICLE INFO: \\ Article History: \\ Received 9 July 2020 \\ Accepted 29 August 2020 \\ Available online 18 September 2020}

\section{Keywords:}

Community;

Urban planning;

Spatial planning;

Decision-making processes.

\section{ABSTRACT}

Participation in decision-making processes foreshadows enabling citizens, communities, non-governmental organizations and other interested parties to influence the formulation of policies and laws affecting them. The purpose of this study is not only to review Lithuanian legal documents but also to analyse recent processes in Kaunas city planning. Kaunas city is undergoing various urban processes, which do not always meet the needs of the community. This study presents an analysis of the forms of community involvement in the urban planning processes and survey data on the effectiveness of community involvement. The methodology requires using a sociological survey with representatives of the city community and a comparative analysis between legal obligations and actual urbanization process.

JOURNAL OF CONTEMPORARY URBAN AFFAIRS (2021), 5(2), 197-208.

https://doi.org/10.25034/ijcua.2021.v5n2-3

www.ijcua.com

Copyright (c) 2020 Laura Jankauskaitè-Jurevičienè, Aušra Mlinkauskienè.

This article is published with open access at www.ijcua.com

\section{Introduction}

Public participation has become an important topic of governance in the $20^{\text {tt }}$ centuryArnstein in 1969 described public participation as follows: "The idea of citizen participation is a little like eating spinach: no one is against it in principle because it is good for you". In her article, the author describes the influence of society in government decision-making as a ladder, where at the bottom of the ladder are Manipulation (first step) and Therapy (second step), at the topmost - (seventh step) are Delegated Power and (eighth step) Citizen
Control (Arnstein, 1969). Today, planning theorists and practitioners actively advocate public participation in spatial planning. Accordingly, Marcus Lane observed that government has been replaced by governance (Marcus, 2005). Activity, due to public participation, is driven by theoretical

*Corresponding Author:

Kaunas University of technology, Civil engineering and architecture faculty, Kaunas, Lithuania

Email address: laura.jankauskaite-jureviciene@ktu.It 
and practical reasons. In practice, public participation is the key of the democratic process. This makes government institutions accountable to the society, enables it to incorporate non-professional knowledge into decision-making, improves public policy support and improves planning outcomes. Participation in itself is valuable as a political goal, as it increases social capital and gives citizens more opportunities when they want a stronger voice in decision-making.

Lithuanian researchers examine the issue of public participation both on a theoretical (legal basis) and on an empirical basis (Bardauskienè, 2007; Jakaitis, 2005; Cirtautas, 2011). However, the activity of society in political life and decision-making is more often examined (Merkys, 2020). In the field of urban planning, the attitude of the population in the formation of urban architecture, the activity of the society in the consideration of urban plans, and the causality of the passivity of the society are most often examined. Examining the articles of foreign authors on sociological research related to public participation, it is noticeable that the connections with certain social aspects are usually examined. Most authors have studied community participation through social and demographic factors and less analysis of the impact of social and physical variables on a given problem (Bottini, 2018).

This article discusses short historical development and the main spatial planning documents related to public participation in spatial planning processes in Lithuania, and the opportunities for residents to express their views and make suggestions on the projects. A pilot sociological survey was conducted using community social networks to find out how active and involved the population is in Kaunas city spatial planning processes. The survey aim was also to understand the activity of the social network, its main audience and the rational for this type of audience.

\section{Materials and Methods}

A pilot study was conducted to analyze public participation in spatial planning by literature analysis and spatial planning documents, raising a hypothesis, conducting the research and drawing conclusions. An analysis of the literature and documents is provided in chapters 3.1 and 3.2. The results of the study are presented in chapter 4 and the conclusions and suggestions in chapter 5.

Historical analysis of public participation in spatial planning was performed to find out the development of involvement in decisionmaking, historical stages, implemented reforms and their impact. The analysis of the most important documents describing the public participation in the territorial planning processes was performed to find out the ways, means and emerging problems of public involvement in the territorial planning processes in Lithuania.

Non-random convenient selection, voluntary sampling was used for the sociological survey. Data were collected using social networks visa-vis: i). Facebook, by submitting a survey on multiple community accounts and sharing the profile through personal accounts. This method of data collection was used purposefully to find out who and the extent of those active in social networks and how much they are interested in territorial planning problems. Before the survey, it was hypothesized that Kaunas city residents were very little interested in participating in the spatial planning processes.

The following sociodemographic variables were examined in the study: Gender, Age, Education, Occupation, Community activities and Place of residence. Analysis in this study is quantitative and Quantitative analysis and IBM SPSS was used for the analysis. The level of statistical significance was defined as $p<0.05$.

\section{Historical and document analysis of public participation in spatial planning}

3.1. Historical analysis of public participation in spatial planning in Lithuania

Changes in the territory of Lithuania are closely related to the political, economical, social and other factors. These factors have a direct impact on the spatial structure of the landscape. Lithuania has undergone many land reforms over the centuries, but land reforms in the last few centuries are of particular importance. According to the Wallachian reform (16th century), the land of all manors was declared as the complete property of the Grand Duke and was combined into one area measured into the Wallachians (about 21.38 ha). The villages were organized and distributed, a three-field system was established. As part of the land reform, towns and church villages were established, manor houses, street-planned and scrappy 
villages, residential areas were also connected with the road network (JankauskaiteJurevičiene, 2016).

From the middle of the 19th century until the middle of the 20th Lithuania territory was managed and used as an individual farming system. At the time of these reforms, public participation in land management was not possible, because land management was sorely within the jurisdiction of the nobility.

The annexation of Lithuania in the 1940s by the Soviet Union began the destruction of traditional, cultural and spiritual values and the creation of new political-social structures collective farms. During the Soviet land reform, private land was nationalized, after which manors and small individual farms disappeared (Jankauskaitè-Jurevičienè, 2016). Thus, the period from the 1940s until 1991 is the collective farm period (Jankauskaitè-Jurevičienè, 2016). Spatial planning activities between 1950-1965 in Lithuania involved the planning of individual objects in a territory and later the planning of administrative district schemes and settlements and industrial objects which were regulated by centralized state administration bodies. It was only after the 1970s when the complexional natural protection scheme and other spatial planning documents were prepared that the management of the territory of Lithuania can be called complex and linked to the management of the whole country (Gurskienè, 2008). However, public participation was not possible in territory planning because of the policies of the Soviet Union.

After the Restoration of the Republic of Lithuania which was March, the rights and obligations of the state and municipal institutions were established on December 12, 1995, by the Law of Territory planning. This law also established the rights and obligations of natural and legal persons in the planning processes. The objectives defined in the Law on Spatial Planning of the Republic of Lithuania are: i) to balance the development of the territory; ii) to create a healthy environment and equal living conditions; iii) to formulate territorial development policy; iv) to preserve, rationalize the use and restore natural resources, natural and cultural heritage values, and maintain or restore ecological balance; $v$ ) encourage investment for socio-economic development; vi) harmonize the interests of the public, non-governmental and governmental organizations regarding the conditions for the use of the territory and land plots and the development of activities in Lithuania territory (Law on Spatial Planning of the Republic of Lithuania, 1995, 2019). Thus, spatial planning is a complex process that combines the interests of the groups interested in spatial development, the needs of society and the protection of the environment.

Major changes in the regulation of spatial planning took place in 2014 and are valid until now. The new regulation aims at simplifying, accelerating and improving the spatial planning process. With the creation of the new spatial planning system, new levels of this planning were established, the principle of parcel planning was abandoned and the projects of land holdings were removed from the system of spatial planning documents. Therefore, it is very important to identify the existing problems in the context of spatial planning, to solve them and not to repeat them in the future (Valstybinio Audito Ataskaita, 2019). In 2020, by the principles of spatial planning currently in force, a new state master plan should be drawn up, which should determine the directions and priorities of spatial development. Following this strategic document, efforts will be made to coordinate various activities in the country: agriculture, tourism, business, cultural heritage protection and infrastructure. To prevent this document from becoming formal, it is necessary to ensure its proper implementation, especially in the field of public participation.

\subsection{Documents defining public rights}

The Constitution of the Republic of Lithuania enshrines the aspiration of the nation to create an open, just and harmonious civil society. Since the right of any society is to have their convictions and to freely express them as guaranteed by the Constitution, this same is enshrined in the Constitution of the Republic of Lithuania in 1992. It is also noticeable that the Lithuania municipal institutions are remote from the majority of the society and often the decisions they make do not meet the needs and interests of the society even if their participation were involved in the preparation of territorial planning documents as defined by the different laws: Law of the Republic of Lithuania on Territorial Planning (Seimas, 2004), Regulations on public information, consultation and participation in spatial planning decisions (Regulations on public information,1996). 
Convention on Access to Information, Public Participation in Decision-making and Access to Justice in Environmental Matters adopted on Aarhus Convention (Ekonomikos komisijos Konvencija, 2001). Certain planning documents for urban problems and their management of urban, social and economic development are widespread in European countries (area-based initiatives, neighbourhood strategies, urban development programmes). These documents are usually advanced examples of harmonious cooperation between local or national/regional authorities and local people (Cirtautas, 2011).

To ensure public participation in the implementation processes of spatial planning in Lithuania, there is a legal obligation to make public all spatial planning documents under preparation. The public shall be given access to get acquainted with the document under preparation stage, submit proposals and comments.
Territorial planning audit control report (2019), which aim to assess whether the system is in place to ensure an effective spatial planning process, provides facts about public participation in spatial planning. According to the data from the restoration of Independence of the Republic of Lithuania in 2019, 73400 territorial planning documents were registered in the spatial planning documents (approximately 2400 documents are registered annually) (Figure 1). This report showed that $12 \%$ of spatial planning documents, prepared in Territorial planning documents preparation and territorial planning process state supervision information system (TPDRIS) of the Republic of Lithuania, did not properly pass the final stage publicity procedures (State Territorial Planning and Construction Inspectorate, 2020). It is also noted that over $50 \%$ of project publicity procedures took place after the approval of the spatial planning documents (Valstybinio Audito Ataskaita, 2019).

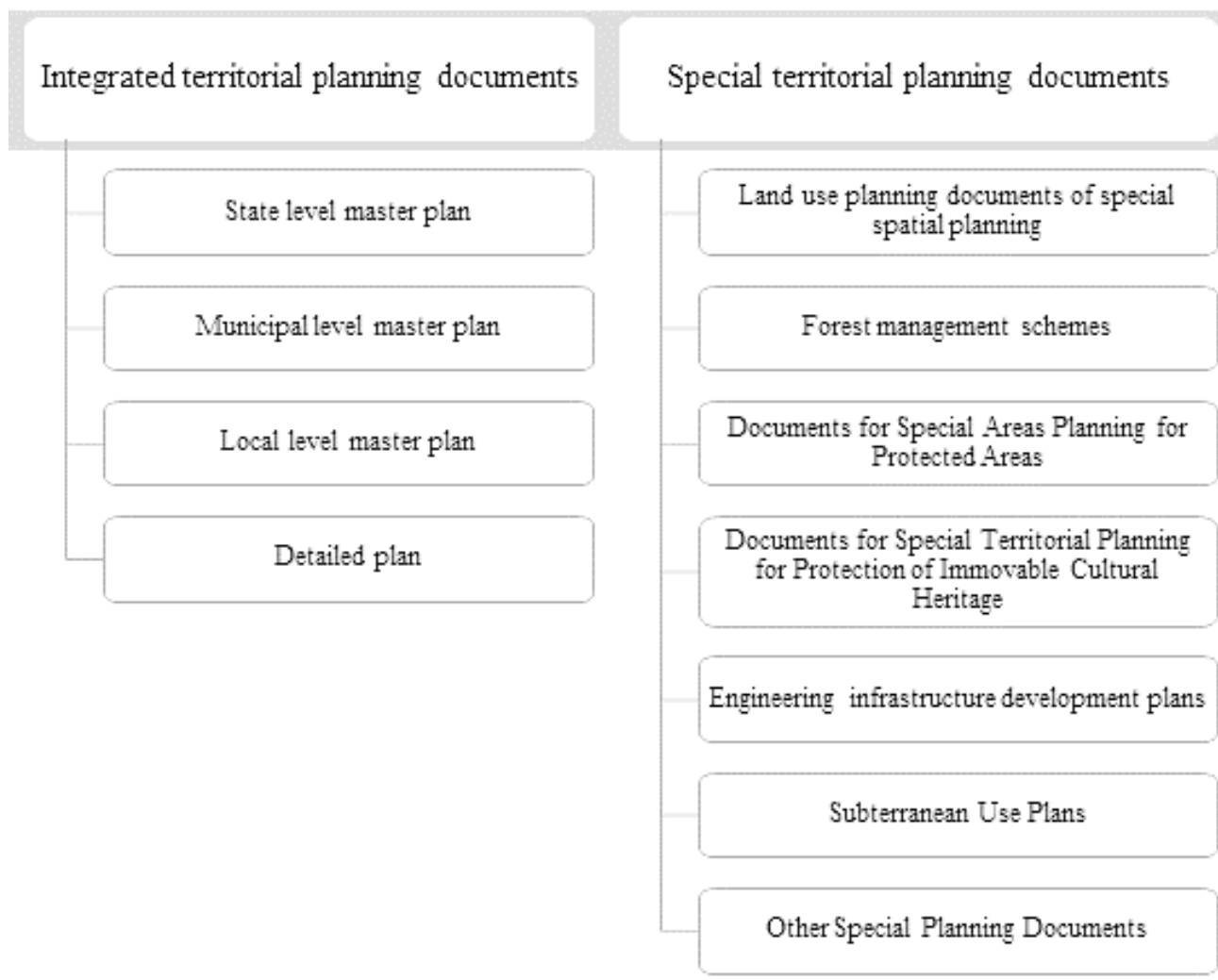

Figure 1. Classification of Territorial Planning Documents.

Several amendments were made regarding the Law of the Republic of Lithuania on Territorial Planning, which came into force in 2014 before it was adopted. The amendments were based on the necessity to speed up the
Planning documents of projects of national importance planning and construction of territories, open the way for investments and to reduce the procedural burden on business. The new version of the law was drafted under intense business pressure from public authorities. This 
social group welcomed the changed regulation in a very positive way. The question, therefore, arises whether the introduction of such business-friendly legal regulation has left the safeguards in place to ensure that the interests of other segments of society are not prejudiced during spatial planning (Lastauskienè \& Bakšienè , 2015).

Following the adoption of the new version of the Law of the Republic of Lithuania on Territorial Planning, many changes have been made to the public's ability to participate in spatial planning. The analysis of Articles 33, 34, 35 of this law and the subordinate legal acts show that in the sphere of public information and participation in spatial planning, the terms of public information and submission of proposals were halved (presumably to speed processes), and only the master drawing, the ad serving in local newspapers was abolished and the information moved to the webspace (i.e. made available only for targeted search). Besides, only registered landowners and land users whose access rights are restricted by the special land use conditions set out in the detailed plan decisions shall be informed by registered mail. To sum up, the concept of a "marginal norm" under which the public can expect to defend an extremely narrow range of interests, defined by specific provisions, and thus unregulated by law, even though existing and the interests of the principle of sustainable development remain outside the remit of legal protection (Lastauskienè \& Bakšienè, 2015). Significant restrictions on public participation in the area are also reinforced by another innovation - distinction between projects of national importance. Although the public is involved in these planning processes in some form, the status of such object is granted by government resolution without informing the public or their representatives. The new legal regulation created a situation in which the municipalities were left responsible for the implementation of an independent function spatial planning, limiting the possibility for them not to approve spatial planning solutions, which creates preconditions for questioning the constitutionality of such regulation (Figure 2).

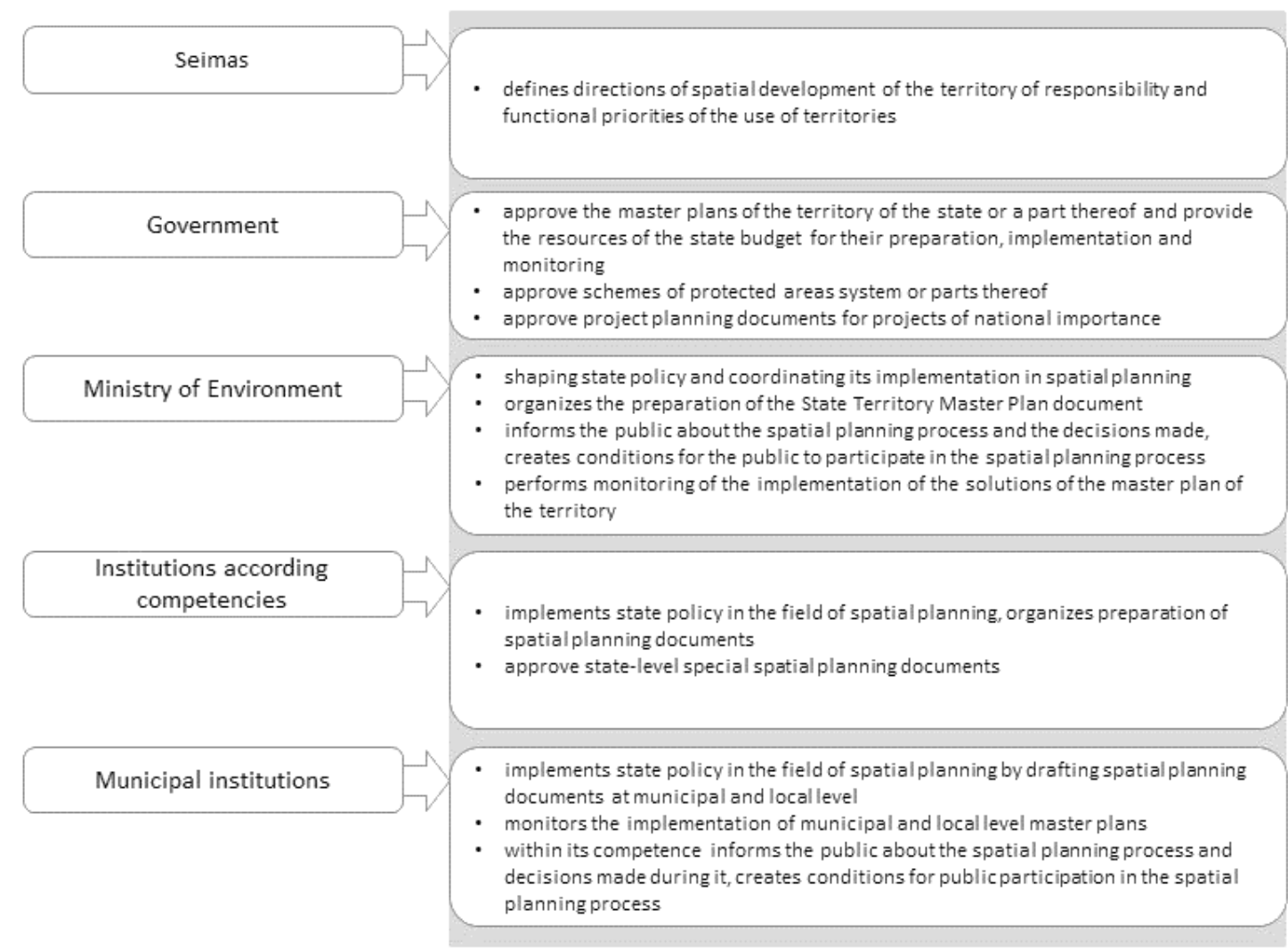

Figure 2. The main institutions involved in the formulation and implementation of spatial planning policy. 
According to Cirtautas, society is involved in urban planning processes in the following ways: i) only by informing it (lowest level), ii) in consultation with it, and iii) allowing its members to participate directly in decisionmaking (highest level). An analysis of the legal acts regulating the territorial planning of the Republic of Lithuania shows that only the first two possibilities of public involvement are mentioned in them (Cirtautas, 2011).

The regulations for information, consultation and participation in spatial planning establish general and simplified procedures for the publication of spatial planning documents, taking into account the type and level of the spatial planning document. The regulations are binding on state and municipal institutions and bodies, legal and natural persons involved in the process of preparation of the spatial planning document, except for territories necessary for national defence purposes (Regulations on public information, 1996). For these regulations, the following procedures shall be made public for the preparation of spatial planning documents: provision of information to the public on the commencement of spatial planning and planning objectives, planning work program; getting acquainted with prepared territorial planning documents; consultation of competent interested organizations or the public concerned; submission and examination of proposals; public discussion of the spatial planning document (Figure 3).

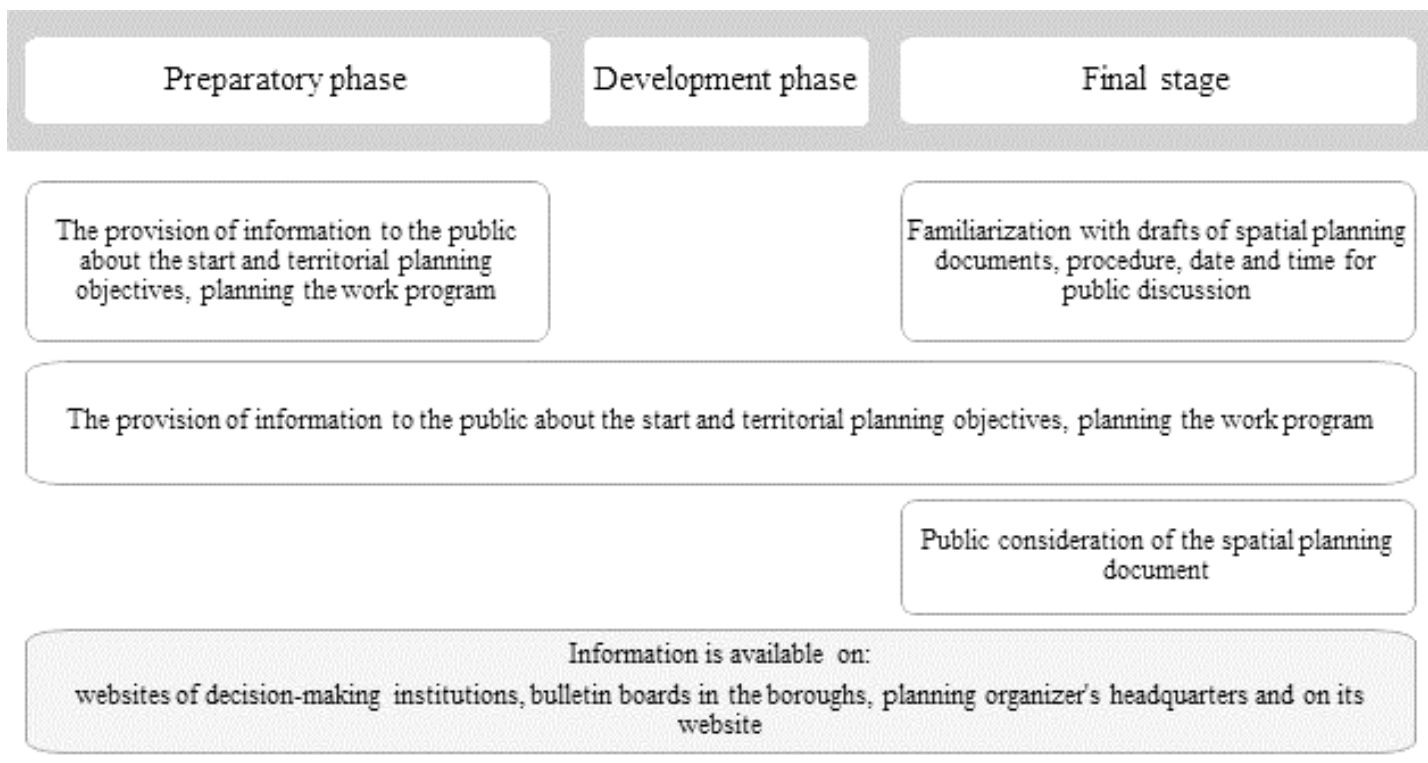

Figure 3. Spatial planning documents publicity procedures.

The Aarhus Convention: links environmental rights with human rights; emphasizes the responsibilities of all of us to future generations; states that sustainability is only possible with the involvement of all stakeholders; states that environmental protection is the government responsibility; focuses on democratic communication between the public and governmental institutions. Each country that has ratified the Convention shall guarantee the rights of access to information, public participation in decision-making, and access to justice in environmental matters (Ekonomikos komisijos Konvencija, 2001).

\section{Community engagement in decision-} making processes in Kaunas urban planning

Kaunas is the second-largest city in Lithuania in the central part of the country, at the confluence of rivers Nemunas and Neris. Kaunas is an important centre for industry, transport, science and culture. The population of Kaunas exceeds 286 thousand (Kaunas, 2019). Currently, many construction projects of various purposes are being carried out in Kaunas. According to the data of 2017, tangible investments by economic activities for real estate operations exceeded $20 \%$ (Kaunas, 2018).

Public participation in spatial planning can take many forms and for different reasons. 
Participation strategies and means of participation also vary and are highly dependent on who organizes the participation and for what purposes. Public participation can take the form of constructive cooperation with planners and local authorities to improve spatial planning projects, or it can be a contradiction in terms of simply rejecting all planning proposals from planners and local authorities. Ideally, public participation should lead to results that are in the best interests of as many participants in the planning process as possible, not just one stakeholder group (European MSP Platform, 2014). To find out the involvement of the public in the decisionmaking of spatial planning documents, a survey involving 44 respondents was carried out. The questionnaire was distributed to Kaunas communities using social networks. The survey consists of few main research constructs: clarification of personal attitudes to participation in spatial planning processes and attitudes towards Kaunas city residents' participation and approach to municipal action in the process of adopting spatial planning documents. Of the 44 respondents, the distribution in the age groups 30-40, 41-50, 51-60 was almost even, respectively: 25,30 and $27 \%$. Interestingly, that 18-29-year-old persons, which according to Lithuanian law correspond to young adults, indicates absence between the respondents; respondents, aged 61 and over, were $20 \%$. The majority of respondents were women (73\%). It is noteworthy, that by education about $88 \%$ of respondents are from higher education - $68 \%$ of respondents are university graduates and $20 \%$ are college graduates. By occupation, $40 \%$ of respondents are specialists and $16 \%$ - public servants. 3 respondents are the chairpersons of the communities (community - residents of a municipal residence connected with the common needs and interests of neighbourhood living, usually with the status of a public body), 2 respondents are subeldership leaders (elected representatives of the community or part of the community with statutory rights and duties) and 16 respondents $(36 \%)$ identified themselves as active members of the community. The majority of the respondents (64\%) consisted of residents of Šančiai eldership (the smallest current administrative-territorial unit in Lithuania, introduced by the Law on Local SelfGovernment of 7 July 1994. Kaunas consists of
11 elderships - Aleksotas, Centras, Dainava, Eiguliai, Gričiupis, Panemunè, Petrašiūnai, Šančiai, Šilainiai, Vilijampolè, Žaliakalnis) and $12 \%$ - the inhabitants of Aleksotas. About 22 thousand people live in Šančiai eldership. It accounts for $\sim 6.9 \%$ (Šančiy, 2016) of the total population of Kaunas city, while Aleksotas population is 20 thousand, which is $6.4 \%$ (Aleksoto, 2019) of Kaunas city population. None of the respondents was from the Center, Petrašiūnai or Vilijampole elderships, and the number of respondents from other elders did not exceed $5 \%$. Such activity of residents of one eldership in answering the questionnaire may be based on 2019 spring disputes with Kaunas Municipality regarding the planned new street in the recreational territory along the Nemunas River. The residents of this eldership actively participated in discussions with the representatives of the municipality to seek the amendments, which were rejected by the municipality, in the general plan of Kaunas city. To the question "How active are you personally in expressing your opinion or making suggestions to the municipal authorities in the preparation of spatial planning documents?" $39 \%$ of the respondent's stated that they are neither passive nor active. However, even more than a third of respondents said they are active $(27 \%)$ and very active (9\%). In finding out the relationship between gender and activity in the community, it was observed that the percentage of responses between the different genders by activity was very similar: $50 \%$ of the male gender asserted they were inactive and $50 \%$ opined that they were active. Accordingly, the female gender rated their activity as follows: $53.1 \%$ inactive and $46.9 \%$ - active. Respondents had to rate their activity level on a 5-point Likert scale. The result obtained by calculating the average personal activity assessment and comparing it between the genders using the T-test showed that there is a very small difference between the groups in the assessment of their activity (average for male $-3,0833$, and for female $-3,1250$ ). To the question, "Do you have enough information about the spatial planning decisions made in the municipality?" as much as $84 \%$ replied that the information is too limited. Moreover, in sourcing information on spatial documents, the question "From what sources do you learn about the projects or decisions being considered in the municipality?" was considered. Respondents were able to select 
several answer variations, but the vast majority (86\%) noted that social networks (eg. Facebook) are the most popular source of information. Respondents also answered that they search for information on spatial planning objects on the municipal website (32\%) and ask active community members (50\%). Only $5 \%$ of the respondents ask the municipality about the issues of spatial planning they are concerned with and none of the respondents replied that they received information about it from the eldership. It was noticed from the survey that Kaunas city residents are equally concerned with personal residential and urban spatial planning problems, but most often, they do not discuss these problems with decision-making bodies, but with friends and acquaintances (89\%). From the graph below (Figure 4), it can be seen that respondents use social networks more often in communicating with municipal representatives on spatial planning documents than participating in project presentation or interviewing authorities. Furthermore, considering that $46 \%$ respondents stated that they did not speak with municipal representatives or submit requests/complaints to the municipality regarding territory planning documents, it can be argued that most respondents only express their views in an informal environment that does not influence spatial planning decisions.

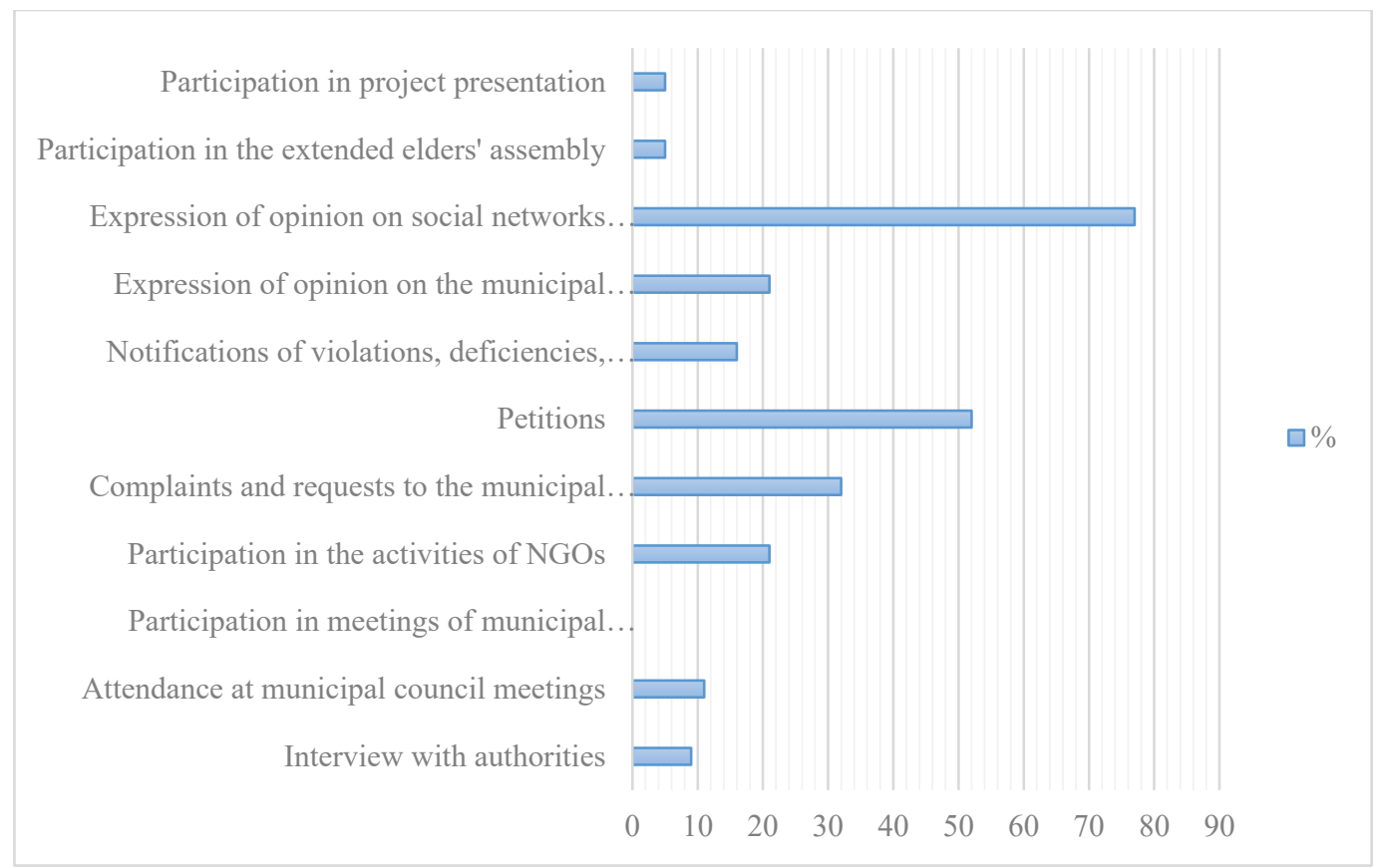

Figure 4. Communication techniques with the municipality used over the last 12 months.

The majority of respondents believe that Kaunas residents are active in seeking to express their opinion or submit proposals for spatial planning documents to municipal representatives (52\%), however, it is not possible to say that the majority of Kaunas city residents think so, as the majority of respondents are residents in one eldership. Probing into respondents' opinion on the reason's citizens do not participate in public decision-making, it was noticed that disillusionment with self-government is prevalent, as participation is not expected to change anything (75\%), they also do not trust their knowledge $-54 \%$ and $66 \%$ respondents think that most citizens lack information on spatial planning processes. Some respondents also chose answers that indicate a lack of personal interest $-36 \%$ have no time for that, or $18 \%$ considers that it is uninteresting to the population. Only $5 \%$ of respondents believe that citizens do not participate in public decision-making because they trust the decisions of council members. Figure 5 below sshow respondents' views on the involvement of citizens in decisions on spatial planning documents. 


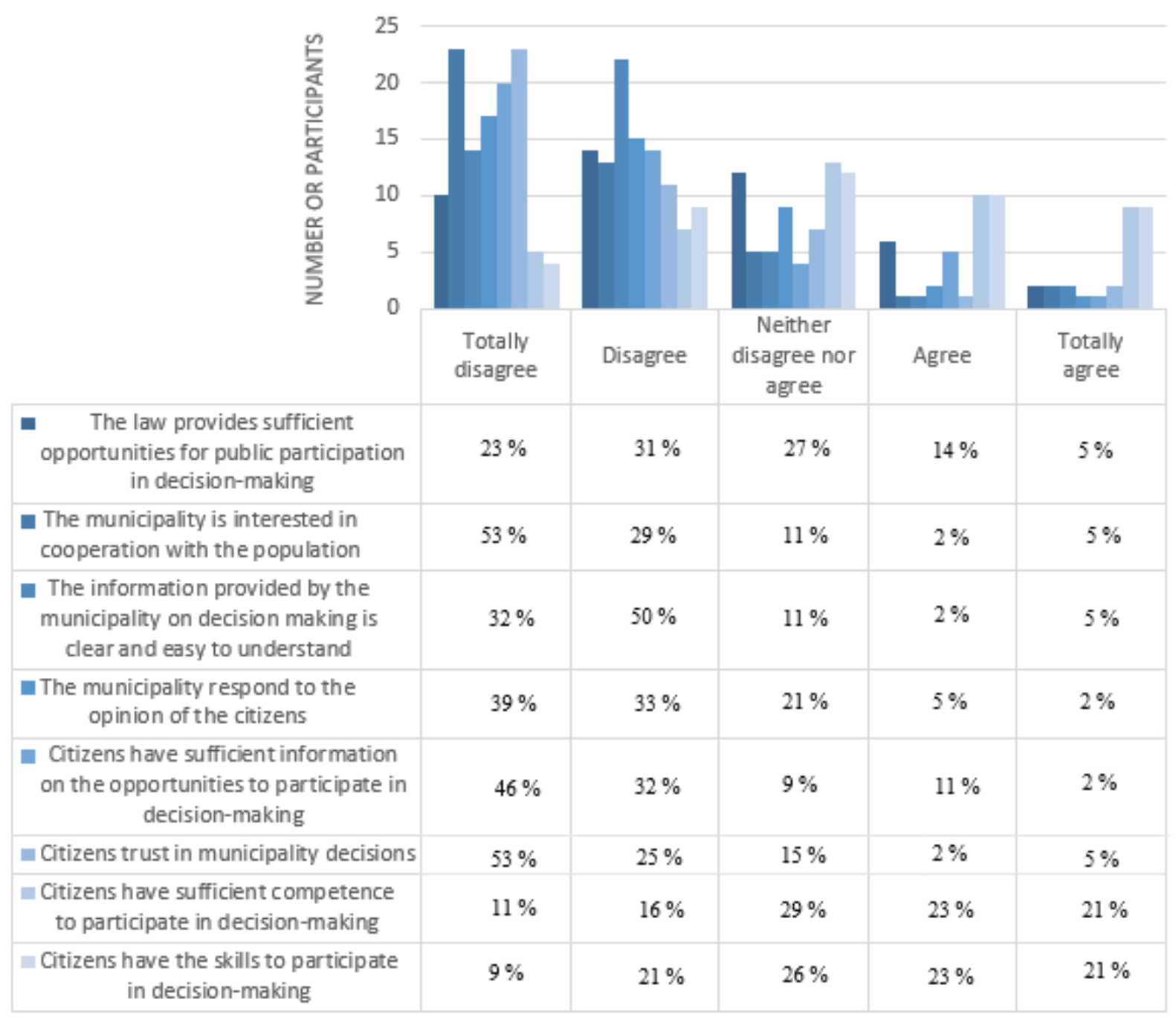

Figure 5. Respondents 'opinion about the citizens' participation in territorial planning document solutions (Survey data).

The statements were formulated according to two research constructs: trust in the municipality and law and the respondents' confidence in their knowledge. Respondents consider that the municipality is not interested in cooperation with the population and the information provided by the municipality is not clear and easy to understand. Nevertheless, even if the municipality does not respond to the opinion of the citizens, according to the respondents, citizens have sufficient information on the opportunities to participate in decision-making and they trust in municipality decisions. From the responses regarding self-confidence, it is observed that respondents, though in doubt, agree that they have sufficient competence and skills to participate in decision-making. Indeed, more than half of the respondents believe that municipality should not only educate the public about ways and opportunities to participate in public decision-making, but also give advice and take greater account of public needs and wishes before making decisions.

The majority of the respondents believe that there is an intense need (84\%) or need $(9 \%)$ for cooperation between the municipality and citizens in making decisions on spatial planning documents.

After conducting a statistical survey on whether there are relationships between the respondents of different education and the evaluation of the actions of the municipality it was observed that education is not significantly related to respondent's attitude to work in the municipality at $95 \%$ significant level.

To examine the relationship between gender and attitudes towards the average evaluation of municipal actions and the average evaluation of citizens' abilities, a T-test was also performed. The group statistics show that there is a very small difference between the average of the groups in the evaluation of municipal 
actions and the average value of citizens' abilities evaluated. The average assessment of the municipality is 2.03 for male gender and 1.9 for the female gender and the average assessment of citizens' abilities is almost equal to 2.5 (ale) and 2.54 (female) respectively.

\section{Discussion and conclusions}

The influence of society on government decision-making has been discussed since the 20th century. Today, various forms of governance are united by the need to directly and centrally involve citizens, nongovernmental organizations and social movements in policy-making and implementation. Lithuanian researchers often simply examine the activity of society in political life and decision-making. In the field of urban planning, the attitude of the population in the formation of urban architecture, the activity of the society in the consideration of urban plans and the causality of the passivity of the society are most often examined. The main spatial planning documents of Lithuania were adopted after the restoration of independence and especially from 1992. Spatial planning documents have changed several times in Lithuania for 30 years. Major changes in spatial planning took place in 2014 and are still valid. This update was intended to simplify, speed up and improve the spatial planning process, the new levels of spatial planning and to show that the principle of individual site planning has been abandoned. To ensure public participation in the processes of implementation of spatial planning in Lithuania, institutions of various levels are legally obliged to make public all spatial planning documents being prepared. The main players in this process are the Ministry of Environment of the Republic of Lithuania and the municipalities of cities and districts, which have to ensure public access to the spatial planning documents in the initial stage and to make suggestions and comments in the later planning stages.

The sample selected for the analysis was 44 respondents. Respondents in the survey are made up of the female gender and middleaged respondents with university or college education, and by occupation are a specialist or public servants. To elucidate the relationship between gender and activity in the community, it is observed that there is a very small difference between the groups in the average assessment of their activity $(0.04$ points). After performing a statistical study and testing the formulated hypotheses at $95 \%$ significant level, it can be stated that the attitudes of respondents with different education to municipality commitments is statically not significant. Nonetheless, conducted data showed that more educated and personally experienced individuals participated in the online survey. From the survey, it was also noticed that the respondents are equally concerned with the urban and personal spatial planning problems of the residential area, but most often they discuss these problems with their friends and acquaintances and use the social networks for spatial planning documents than participation in project presentations or interviews with authorities. The analysis on the relationship between gender and attitudes to the averages of the evaluation of municipal actions and the evaluation of citizens 'abilities revealed that there is a very small difference between the average of groups (men, women) in the evaluation. Overall, response to the hypothesis that that Kaunas city resident is not very interested in territorial planning processes becomes imperative. To this, this study posits that owing to the nonrandom convenient selection, voluntary sampling and conclusions on the general public cannot be drawn. To obtain more accurate unambiguous data, the sample of the survey should be expanded and other methods of sample selection should be used. Because of the changes in the legal regulation (such that the construction is in most cases possible without a detailed plan, establishing an exhaustive list of cases in which the public interest is protected, limiting the creativity of spatial planning by linking it exclusively to public administration procedures, and reduced public access to procedures amongst others), the needs of society in the processes of spatial planning may not be heard at all. Such trends, according to the respondents in the survey are not in line with the modern concept of human rights and Lithuania's international obligations under the Aarhus Convention. This study, therefore, asserts that this situation is unfavourable to the protection of the interests of society as a whole and will undoubtedly create new challenges for the courts which should play a more active and creative role in assessing whether spatial planning solutions 
comply with the principle of sustainable development.

\section{Acknowledgements}

This research did not receive any specific grant from funding agencies in the public, commercial, or not-for-profit sectors.

\section{Conflict of interests}

The authors declare no conflict of interest.

\section{References}

Aleksoto, S. (2019). Aleksoto seniūnija [Aleksotas eldership]. Kaunas City Municipality.

Arnstein, S, R. (1969). A Ladder of Citizen Participation. Journal of the American Planning Association, 35(4), 216-224. https://doi.org/10.1080/01944366908977225

Bardauskienè, D. (2007). Miesto bendrasis planas ir ekspertiniai vertinimai [City master plan and expert assessments]. Town Planning and Architecture, 31(3), 119-130. https://doi.org/10.3846/13921630.2007.10697098

Bottini, L. (2018). The effects of built environment on community participation in urban neighbourhoods: an empirical exploration, 81(1), 108-114. https://doi.org/10.1016/j.cities.2018.03.020

Cirtautas, M. (2011). Visuomenès dalyvavimo urbanistinio planavimo ir projektavimo procesuose realijos ir perspektyvos [Reality and perspectives of public participation in urban planning and design processes]. Mokslas - Lietuvos Ateitis / Science Future of Lithuania, 3(3), 59-66. https://doi.org/10.3846/mla.2011.052

Constitution of the Republic of Lithuania. (1992). Lietuvos Respublikos Konstitucija [Constitution of the Republic of Lithuania]. Lietuvos Aidas, Nr. 220 (1992-11-10).

https://www.lrs.lt/home/Konstitucija/Konstitucija. htm

Ekonomikos komisijos Konvencija, J. E. (2001). Dèl teisès gauti informaciją, visuomenès dalyvavimo priimant sprendimus ir teisès kreiptis i teismus aplinkosaugos klausimais [Convention on access to information, public participation in decisionmaking and access to justice in environmental matters], Valstybès žinios.

European MSP Platform . (2014). A Handbook on Territorial Democracy and Public Participation in Spatial Planning. 16th session of the Council of Europe Conference of Ministers responsible for
Spatial/Regional Planning (CEMAT), 17 June 2014, Nafplion.

Gurskienè, V., Tarvydienė, M. E. (2008). Teritoriju planavimas. Mokomoji knyga [Territory planning. Educational book]. Arvida, Kaunas.

Jakaitis, J. (2005). Miesto architektūros savitumas kaip architektūros ir visuomenès sąveikos rezultatas [The peculiarity of urban architecture as a result of the interaction of architecture and society]. Urbanistika ir architektūra, 29 (4), 191-202.

Jankauskaite-Jureviciene, L., Mlinkauskienè, A., \& Stanaitienè, V. (2016). Lithuanian rural landscape change trends and consequences after the restoration of the independence. Lucrări Științifice, Universitatea de Stiințe Agricole Și Medicină Veterinară" Ion Ionescu de la Brad" Iași, Seria Horticultură, 59(1), 177-182.

Kaunas. (2018). Kaunas basic data. Kaunas City Municipality.

Kaunas. (2019). Kaunas basic data. Kaunas City Municipality.

Lastauskienė, G., \& Bakšienė, D. (2015). Visuomenès interesų apsaugos problema planuojant teritorijas [The Problem of Protection of Public Interest in spatial planning]. Teise, 960. 52-70. https://doi.org/10.15388/Teise.2015.96.8757

Marcus B. L. (2005). Public Participation in Planning: an Intellectual History. Australian Geographer, 36(3), 283-299.

https://doi.org/10.1080/00049180500325694

Merkys, G., Bubelienė D. (2020). Šiaulių miesto gyventojų nuomonès apklausa ir tyrimas [Survey and research of Šiauliai city residents' opinion] Šiauliai City Municipality, Šiauliai.

Regulations on Public Information. (1996) . Visuomenès informavimo, konsultavimo ir dalyvavimo priimant sprendimus dèl teritoriju planavimo nuostatai [Regulations on Public Information, Consultation and Participation in Spatial Planning Decisions]. TAR, suvestine redakcija/Consolidated version.

Seimas, L. R. (2004). Lietuvos Respublikos Teritoriju planavimo istatymas [Law of the Republic of Lithuania on Territorial Planning]. Valstybès žinios.

Šančių S. (2016). Šančiai eldership [About us]. Kaunas City Municipality, Kaunas. 
Valstybinio Audito Ataskaita. (2019). Teritorijų planavimas [Public audit report. Territory planning]. National Audit Office of Lithuania, Supreme Audit Institution.

How to cite this article:

Jankauskaitè-Jurevičienè , L., \& Mlinkauskienè, A . (2021). Community Participation in Decision Making Processes in Urban Planning: The Case of Kaunas. Journal of Contemporary Urban Affairs, 5(2), 197-208. https://doi.org/10.25034/ijcua.2021.v5n2-3 